Braun D, Popa SA. This time it was different? The salience of

the Spitzenkandidaten system among European parties. West European Politics (2018)

DOI link

https://doi.org/10.1080/01402382.2017.1419003

ePrints link

http://eprint.ncl.ac.uk/246163

Date deposited

$22 / 02 / 2018$

Embargo release date

$30 / 09 / 2019$

Copyright

This is an Accepted Manuscript of an article published by Taylor \& Francis in West European

Politics on 30/09/2019, available online: https://doi.org/10.1080/01402382.2017.1419003 


\title{
This time it was different? The salience of the Spitzenkandidaten system among European parties ${ }^{1}$
}

\begin{abstract}
The Lisbon Treaty (2009) introduced key institutional changes to increase the relevance of elections to the European Parliament (EP). Among others, major political groups nominated different lead candidates, the so-called Spitzenkandidaten, for the 2014 EP elections. The aim of this paper is to investigate how national political parties react to this new institutional setting. Using data from the 2014 Euromanifesto study, we examine if and under what conditions political parties put emphasis on the Spitzenkandidaten system in their party manifestos. Moreover, we are interested in finding out if parties take positive or negative stances when talking about it. Our findings reveal that parties put little emphasis on the issue. Moreover, the factors promoting the Spitzenkandidaten system suggest that parties decide strategically upon emphasizing that topic or take a positive stance on it if they expect to benefit from this.
\end{abstract}

\section{Keywords}

Elections, European Parliament, European Union, Spitzenkandidaten, Lead Candidates, Party Behavior, Manifesto Data

8,714 words (excluding tables, graphs, and appendices)

\begin{abstract}
Authors
Daniela Braun

LMU Munich/ MZES, University of Mannheim (External Fellow)

daniela.braun@gsi.uni-muenchen.de
\end{abstract}

Sebastian A. Popa

MZES, University of Mannheim and Newcastle University

Sebastian.Popa@mzes.uni-mannheim.de

\footnotetext{
${ }^{1}$ Research on which the paper is based was supported by the EUENGAGE project funded under the Horizon research and innovation programme (grant agreement No 649281 - EUENGAGE - H2020-EURO-20142015/H2020-EURO-SOCIETY-2014).
} 


\section{Introduction}

The Lisbon Treaty (2009) introduced key institutional changes to increase the relevance of elections to the European Parliament (EP) (for a good overview, see Corbett 2014, Hobolt 2014; Christiansen 2016; Maier et al. 2017). Among others, major political groups nominated different lead candidates, the socalled Spitzenkandidaten, for the 2014 EP elections. Although the formulation within the treaty was rather ambiguous in this regard, it can roughly be summarized that the candidate of the winning party group is supposed to be elected by the majority of MEPs as President of the European Commission. After some negotiations between the actors of the EP and the heads of government of some member states in the aftermath of the 2014 EP elections, this was finally put into practice with the election of Jean-Claude Juncker as President of the European Commission. The idea behind this innovation was to give European elections, and consequently elected political actors, more weight in the European Union (EU) multi-level system of governance. This should to a certain degree contribute to the legitimacy issues of the EU. Less surprising so that the official slogan spread ahead of these elections was 'This time it's different' (European Parliament 2014) with the expectation in mind to finally create a genuine electoral contest and to strengthen the electoral connection. The introduction of these key institutional changes has found support by scholars of EU studies advocating such a European contest e.g. "via a battle for the Commission President, with governments and national and European parties backing different candidates and policy platforms" (Follesdal and Hix 2006: 557) for a long time.

But did this institutional change indeed increase the relevance of elections to the EP? Where these elections really different? The findings from empirical studies at hand point into a different direction: First, the Spitzenkandidaten were widely not visible during the election campaign (Gattermann et al. 2016; Schulze 2016). Second, only few citizens were able to link the candidates to the correct party: " $19 \%$ of respondents recognized Juncker and $17 \%$ of them recognized Schulz. These numbers are even lower for the candidate of the smallest of the three political groups [...]" (Schmitt et al. 2015: 357). Third, the 'Eurovision debate', a discussion among the Spitzenkandidaten broadcasted on TV, radio, and via the internet throughout Europe was watched e.g. in Germany "by 160,000 
viewers, less than one per cent of the national debate audience" (Maier et al. 2017: 17). Accordingly, the main question is how we can explain these high theoretical expectations in face of the institutional changes together with the rather sobering consequences empirical studies have revealed so far.

In our opinion, the behavior of political parties gives an important clue to understand this puzzle. Although we know that EP elections are different from national elections for many reasons (Hix 2005: chapter 6; but see also the second order election model as for the first time presented by Reif and Schmitt 1980), (national) political parties ${ }^{2}$ are the main actors in EP election campaigns and thus should - at least in theory - have had the potential to deploy the institutional changes in order to make the 2014 EP elections different. Nonetheless, we argue that the political parties did behave in a different way, mainly because they are constrained by two important factors: a) the considerations that guide party's behavior as strategic actors, and b) the complexity of party politics within the EU multi-level structure. This interplay leads to the fact that the changes within the Lisbon Treaty were not as far reaching as expected (for a similar guess, yet without empirical testing, see Franklin 2014). Against this background, the general aim of our paper is to study if and under what conditions political parties did make use in their campaign of this new feature of party competition at the EU level of governance. Did they put emphasis on the Spitzenkandidaten system in their election manifestos? Did they frame it negatively or positively?

The paper is structured as follows: To begin with, we summarize briefly the state of the art on the institutional changes. In a second step, we formulate our theoretical assumptions combining the more general literature on strategic party competition with the particularities of the EU multi-level system. Next, we run our empirical analysis comprising three steps: Using data from the 2014 Euromanifesto study (Schmitt et al. 2016), we first examine descriptively if and what kind of parties put emphasis on the Spitzenkandidaten system in their party manifestos issued ahead of EP elections.

\footnotetext{
${ }^{2}$ It is important to note that not the EP party groups-and outside parliament, the transnational parties or party federations-compete for votes in EP elections, but the national political parties. The candidates to be elected as MEPs are nominated by the national political parties of each EU member state separately. Consequently, these actors are running in the election campaign and, in the majority of the cases, release their own election programs ahead of the EP elections - their so-called Euromanifestos (EMs).
} 
Then we analyze whether parties take positive or negative stances when talking about these lead candidates. Finally, we explore the determinants of parties' emphasis on and position towards the Spitzenkandidaten system.

\section{What do we know about the Spitzenkandidaten system in the 2014 EP elections?}

To begin with, five of the seven party groups nominated Spitzenkandidaten before the EP elections in June 2014: Jean-Claude Juncker for the European People's Party (EPP), Martin Schulz for the European Socialists (PES), Guy Verhofstadt for the Alliance of Liberals and Democrats for Europe (ALDE), José Bové and Ska Keller for the European Green Party (EGP), and Alexis Tsipras for the European Left (EL). The Eurosceptic political groups, i.e. the European Conservatives and Reformists (ECR) and the Europe for Freedom and Democracy (EFD), on the contrary, decided not to put forward candidates. The selection procedures for the candidates were more or less comparable among the different party groups (Put et al. 2016). With regard to their electoral campaign, the five candidates had a total budget of 4.5 million Euros, which was used, among others, for altogether nine televised debates between the Spitzenkandidaten, visits to classical campaigning events, and the promotion of their online presence (Pop 2014; Schmitt and Teperoglou 2015).

But what do we know about the actual role and the impact of these Spitzenkandidaten in the 2014 EP elections so far? Corbett (2014) opened the academic debate in this regard, raising the question whether the new institutional arrangements within the Lisbon Treaty may lead to a reevaluation of the classification as second-order elections. His tentative answer is that EP elections will remain less important elections for the majority of voters, although he admits that the lead candidate system made some difference in election campaigns: First of all, with some exceptions (e.g., the British Labour Party and the Italian Partito Democratico, which abstained from approving Martin Schulz as their candidate), most of the national parties were committed to the candidates of their group. Second, major country differences are observed: While, for example in Germany, televised debates between 
the candidates took place and attracted a considerable TV audience, in other countries almost none event could be observed. These findings are strengthened by a three-country study concluding that little attention was paid to the Spitzenkandidaten (Schulze 2016). Nevertheless, similarly as in the above-mentioned studies, major country differences were striking: whereas the British coverage of that topic was extremely low, French and German newspapers referred more frequently to the Spitzenkandidaten. Furthermore, the Spitzenkandidaten also had a substantive social media presence (Nulty et al. 2016)

More clear-cut findings on the question whether the innovation affected the $2014 \mathrm{EP}$ elections can be drawn from more quantitative approaches. These studies most importantly show that country effects are at play: People were most knowledgeable of specific candidate names in the home countries of the Spitzenkandidaten. Moreover, citizens' awareness of the fact that candidates were nominated varied strongly among countries (Hobolt 2014; Schmitt et al. 2015). Making use of an EUwide representative study, Schmitt et al. (2015) offer some additional findings, which show that the awareness of the Spitzenkandidaten had a modest but statistically significant impact on turnout. To be more specific, the ability of citizens to recognize the Spitzenkandidaten and the campaign activities had an impact on their electoral participation. A most recent quasi-experimental study shows that not only voter behavior, but also citizens' attitudes are affected in this regard (Maier et al. 2017): The exposure of young and well educated citizens to the EU-wide televised debate among the candidates led to increased political involvement as well as stronger support for the union. Although the effects are rather minor in the case of the two latter studies, the authors assume that they could be more substantial in future elections given that this new institutional setting, implemented for the first time, has neither been fully established yet nor clearly defined (in this latter aspect, they strongly agree with Corbett 2014, Christiansen 2016, and Gattermann et al. 2016). 


\section{The Spitzenkandidaten system and the behavior of (national) political parties}

As described in the first part of this article, the introduction of these institutional changes was sought to address one of the most fundamental problems of the EU, i.e. the democratic deficit. Hence, one would have liberally anticipated political parties to take the opportunity to make the Spitzenkandidaten system accessible to their voters: i.e. to explain them how this institutional change can contribute to enhance the legitimacy of the EU, or to criticize it. Nevertheless, the findings of previous studies suggest that a political debate on this - initiated by the political parties - simply did not take place. The crucial question, not least for the future of the Spitzenkandidaten system, is to understand the reasons thereof. In doing this, we ask two main questions: What are the reasons for which parties should or shouldn't emphasize the Spitzenkandidaten topic and through what frame (i.e. positive or negative) they should approach it? ${ }^{3}$ We will discuss the underlying behavioral alternatives in the following paragraphs and derive empirically testable hypotheses. In doing so, we draw on the major insight that "[a]ccording to the stipulated objectives of political parties, we can distinguish between (1) vote-seeking, (2) office-seeking, and (3) policy-seeking models of party behavior" (Strom 1990: 566; but see also Müller and Strom 1999). In addition, given that the previous discussed theoretical framework has been developed mainly for national parties acting in their national context, we will also borrow from the literature concentrating on the EU multi-level system of governance to develop our hypotheses.

The office-seeking party/ EP party groups: "[...] what parties fundamentally seek is to win, and in parliamentary democracies, winning means controlling the executive branch, or as much of that branch as possible" (Müller/Strom 1999: 5). This is certainly more complicated in the case of EP

\footnotetext{
${ }^{3}$ Scholars generally agree that the party's decision on the topics to be addressed in their election campaigns is as important as the position they take towards an issue (Green-Pedersen 2007; Green and Hobolt 2008; Meguid 2008; Wagner and Meyer 2014). To understand the reasons why parties, emphasize some issues and neglect others, most researchers go back to the theoretical foundations of salience theory, put forward by Budge and Farlie (1983), as well as issue ownership theory (Petrocik 1996; Petrocik et al. 2003). Nevertheless, due to the fact that we want to study why and how political parties did deal with the Spitzenkandidaten system, we decided to draw upon a theoretical framework which enables us to explain the genuine party behavior, instead of the (certainly related) issue emphasis theory.
} 
elections, since the election did not lead to some kind of EU government, at least before the $2014 \mathrm{EP}$ elections. After the introduction of the Spitzenkandidaten system at the time of the 2014 EP elections, such an office-seeking argument is indeed more applicable. As a matter of course, not all (national) parties can be equally characterized by their office-seeking goals. Some might have more incentives in this regard, i.e. to get their candidate into the position of the Commission's president. Hence, in order to apply the idea to EP elections, it is important to take into account the support of the national party for the candidate in question: In this line of reasoning, parties or EP groups supporting a certain candidate could be potentially characterized as office-seeking parties. Scattered anecdotal evidence points indeed to the fact that most parties belonging to an EP party group which nominated a candidate did indeed actively campaign on behalf of the candidate. In this context, the case of Schulz is most illustrative, who greatly benefited from the extensive support of SPD in Germany and PSOE in Spain throughout the entire campaign (Peñalver García and Priestley 2015). In contrast, parties belonging to the two Eurosceptic political groups, the European Conservatives and Reformists (ECR) and the Europe for Freedom and Democracy (EFD), did not even nominate a candidate. This creates an obvious difference in the incentive structure resulting from the office seeking motivation between parties that did nominate and those who did not nominate a candidate ${ }^{4}$. Accordingly, we assume that political parties competing for the office, i.e. those belonging to an EP party group are more likely ...

H1.1: ... to emphasize the Spitzenkandidaten topic (i.e. their names and the system) in their Euromanifestos.

H1.2: ... to take a more positive stance towards the Spitzenkandidaten topic in their Euromanifestos.

Another point that needs to be taken into account, when considering the difference among EP party groups is that their approach towards the topic goes beyond office seeking behavior and is somehow closer to the vote-seeking rationale of the party. As internal dissent alters the perception of policy coherence rendering thus information acquisition regarding the party more difficult, this negatively influences voters' perceptions of parties' competence and ultimately how voters evaluate

\footnotetext{
${ }^{4}$ Besides ECR and EFD, non-affiliated parties are also in the same situation.
} 
the party (Greene and Haber 2015). Thus it comes naturally that parties or party groups are less likely to emphasize issues on which dissent is recorded (Edwards 2008; Hellström and Blomgren 2015; Steenbergen and Scott 2004; van de Wart 2015) as such consideration would have a negative impact on their electoral fortunes and be conflicting with their vote-seeking motivation. In the case of the topic under consideration, the EPP party group stands out as being the only party that followed an internally contested nomination procedure. ${ }^{5}$ This is not to say that the nomination of the other candidates by their respective party was unanimous. But, while the other groups either had only one candidate (as in the case of PES, ALDE and EL) - who received broad support by a formal vote during the parties' congress (they obtained the support of at least $80 \%$ of party delegates) - or had nominated as candidates both contenders (as in the case of EGP), this did not apply to the EPP (Put et al. 2016). In this latter case, there was an open contest between Jean-Claude Juncker (supported by CSV from Luxembourg, CDU from Germany and ND from Greece) and Michel Barnier (supported by FIDESZ from Hungary and NSi from Slovenia) for the nomination of the group. This resulted in a rather close election during the Dublin party conference (6-7 March 2014), ultimately won by Juncker with 382 votes, i.e., $61 \%$ of the total votes (Barnier only got 245), and had potential consequences for the cohesiveness of the EPP regarding the support for the Spitzenkandidaten. Thus, we expect that party groups which registered little dissent in terms of supporting a certain candidate should have an incentive to put emphasis on the Spitzenkandidaten system and frame it positively. Hence, compared to EP groups which nominated a candidate without a greater degree of intraparty dissent, parties belonging to the EPP party group are less likely ...

H2.1: ... to emphasize the Spitzenkandidaten topic in their Euromanifestos.

$\mathrm{H} 2.2$ : ... to take a more positive stance towards the Spitzenkandidaten topic in their Euromanifestos.

\footnotetext{
${ }^{5}$ Ideally, we would investigate the role of internal cohesion by exploiting the difference between parties who supported the party candidate during the internal nomination procedure and those who opposed the candidates or abstained from the vote. Unfortunately getting the voting records from each party group for the nomination procedure was not possible either because the vote was secret (the case of EEP and PES), or parties were not willing to grant us access to the voting records (the case of ALDE and EL) or because the nomination procedure was open to all citizens (the case of the EGP).
} 
The vote-seeking party/ party supporters' position towards Europe: Beside the idea that vote-seeking parties are parties without a greater intraparty dissent in terms of the candidate nomination, it is uncontested that political parties seek "to maximize their electoral support" (Müller/Strom 1999: 8). One of the most effective strategies to do so is to position themselves in such a way towards political issues that they are appealing to their potential voters. In fact, there is substantial research showing that parties adapt their positions in response to the the stances of party supporters (Adams et al. 2014). This is particularly the case for EU-related stances (Popa and Dumitrescu 2015; Steenbergen et al. 2007). Following the above logic, if party supporters are against the EU, the party might thus decide against emphasizing in their official document an institutional change that should at least in theory increase the legitimacy of the EU. Consequently, the anti-pro EU position of the party's supporters ...

H3.1: ... is positively related to the degree to which the party emphasizes the Spitzenkandidaten topic in their Euromanifesto.

H3.2: ... is related to the stance towards the Spitzenkandidaten topic as reflected in their Euromanifesto.

The policy-seeking party/ party position towards Europe: In pursuing their electoral strategy, parties are constrained not only by their office- or vote-seeking goals as described above, but also by their policy considerations. A party "seeks to maximize its impact on public policy" (Müller/Strom 1999: 7). Translating this idea to our case, it means that some parties have more incentives to promote the Spitzenkandidaten topic, because they want to manipulate a particular policy. One important point to remember in this regard is fact that the Spitzenkandidaten topic is not merely a procedural aspect itself (such as amendments in terms of electoral laws), but it is meant to address one of the most fundamental problems of the EU, i.e. to contribute resolving the democratic deficit. Given the particular role of this innovation, we argue that pro-EU parties should have an incentive to promote the Spitzenkandidaten system and present it in a positive light. To be more specific, given that the democratic deficit of the EU is one of the main arguments anti-EU parties use to make their case against the union, addressing the Spitzenkandidaten topic, as a potential solution for this problem, should 
represent an important policy goal for pro-EU parties. The rationale to promote the Spitzenkandidaten topic as a policy is further reinforced when taking into account the standard assumption concerning party competition at the EU level, i.e. that EP elections are still considered as less significant secondorder elections compared to national ones (Hix and Marsh 2011; Reif and Schmitt 1980; Schmitt 2005; Schmitt and Toygür 2016). In this context, EU-positive parties should have an additional incentive to promote a policy that offers the opportunity to enhance the visibility of EP elections and consequently increase the relevance of EU level politics.

Nevertheless, in arguing for the connection between the pro-anti EU position of a party and its policy motivation we need to be careful in distinguishing their EU stances with their attachment to a certain EP group. The point is that even parties belonging to an EP group that nominated a candidate can be in a position to ignore or even criticize the Spitzenkandidaten system, depending on their antipro EU position. Most illustrative examples for this case are several parties from the Confederal Group of the European United Left - Nordic Green Left, which supported Alexis Tsipras. Even if their candidate is not clearly Eurosceptic, eight out of the 20 parties that belong to this group adopt Eurosceptic stances according to the 2014 Chapel Hill Expert Survey data. ${ }^{6}$ We would thus expect these anti-EU parties to either ignore the Spitzenkandidaten topic or to criticize it. ${ }^{7}$ Accordingly, we assume that the anti-pro EU position of a party ...

H4.1: ... is positively related to the degree to which the party emphasizes the Spitzenkandidaten topic in their Euromanifesto.

$\mathrm{H} 4.2: \ldots$ is related to the stance towards the Spitzenkandidaten topic as reflected in their Euromanifesto.

\footnotetext{
${ }^{6}$ To be more specific, eight parties belonging to this group, i.e., Communist Party of Bohemia and Moravia, People's Movement against the EU, Left Alliance, Left Front Sinn Fein, Socialist Party, Portuguese Communist Party and Left Party, have a score lower than 3 on the EU_POSITION variable (measured on a scale ranging from 0 to 7 ) in the 2014 Chapel Hill Expert Survey.

${ }^{7}$ This can also be the case for parties which have an ambiguous position towards the EU even if they are part of a clear-cut pro-EU EP group (i.e., ALDE, EPP and S\&D).
} 


\section{Methods and data}

In order to test our assumptions, we make use of the EES 2014 Euromanifesto Study (Schmitt et al. 2016). The study collected all manifestos of the relevant parties competing in the 2014 EP elections, which are digitized in a machine-readable format and then manually coded by country experts. For coding an updated version of the Euromanifestos Coding Scheme (EMCS) has been employed (see Braun et al. 2015). This coding scheme is an extension of the one used by the MARPOR (former MRG/CMP) project, though the Euromanifesto coding scheme clearly focuses on the content of EP elections instead of national election manifestos of political parties. Our final data set consists of the coded manifestos of the 199 relevant parties (the number also includes the six manifestos of the EP party groups) across the $28 \mathrm{EU}$ member states in the $2014 \mathrm{EP}$ elections. Making use of this data, we can measure both the attention (i.e., emphasis) that parties devote to the Spitzenkandidaten topic and the position they take in this regard.

But what do we actually measure when using this kind of data? In line with manifesto research, it can be assumed that issues which are emphasized by political parties in their manifestos are to a large extent consistent with the policies they advocate in parliaments and governments (Braun et al. 2016; Budge et al. 2001; Wüst and Schmitt 2007). Moreover, they are also the campaign documents that are most likely to represent the collective internal expression of a party (Ceron 2012). Consequently, despite the common criticism that manifestos are drafted by a rather small group of experts within a party, we can act on the assumption that the content of election manifestos reflects the official position a party covers on a specific issue. In our case, the space a party dedicates to the Spitzenkandidaten system thus reflects the general relevance of this topic for the party. ${ }^{8}$

\footnotetext{
${ }^{8}$ Although one can argue that we do not use an appropriate data source, because the EP groups announced their nominations after the parties have drafted the Euromanifestos, this can be refuted since the idea of a new institutional setting including the idea of the Spitzenkandidaten system has been debated already years before (Christiansen 2016). Consequently, all parties had the chance to cover the topic in their manifestos by pointing to the institutional innovation as such and not necessarily mentioning the candidate (in case that the nomination happened too late). In practice, although being initially among the main promoters of the system, only the EPP announced the nomination of Juncker rather late, in early March 2014 (Put et al. 2016), while the other EP groups announced their candidate at least four months before the elections. In the case of PES, it was clear that Martin Schulz was the candidate since early November 2013, ALDE agreed that Guy Verhofstadt would be the only
} 
Dependent variables: In order to measure emphasis, we calculate the proportion of the party manifestos that parties devote to the Spitzenkandidaten topic. As mentioned previously, the space a party devotes to a certain issue in its manifesto is indicative of the salience of the given issue for the party (see for example Budge et al. 2001). It needs to be mentioned that we differentiate in our coding scheme between the Spitzenkandidaten as a general issue and the mentions of the specific candidates. ${ }^{9}$ For the purpose of this paper, we merged the two sub-categories (i.e. Spitzenkandidaten as the general issue and the mentions of the specific candidates.), as they both reflect the attention that parties give to the Spitzenkandidaten system in general. Thus, our first dependent variable, i.e., Spitzenkandidaten salience, captures the attention that parties devote to the issue in general. To measure our second dependent variable, i.e., the position that parties take on the Spitzenkandidaten, we make use of the difference between the negative and positive mentions on the Spitzenkandidaten (again, we merge the two categories). Following Lowe et al. (2011), we measure the framing of the issues as $\log ($ total pos +0.5$)-\log$ (total neg +0.5$)$, with high values indicating a positive tone and low values indicating a negative tone.

Independent variables: For measuring our independent variables, we use several sources. To measure if the party supported a candidate $(\mathrm{H} 1)$ or whether there was an internal debate over this support ( $\mathrm{H} 2)$, we rely on the predicted EP party group that they would join after the election according

candidate in January 2014, the European Greens also announced in January 2014 their decision to nominate the Ska Keller-José Bové duo while the European left nominated Alex Tsipras as their candidate in December 2013. In addition to that our findings later in the paper show that parties devote a similar level of attention to both specific mentions and the general mention of the system (the 37 parties who mentioned the Spitzenkandidaten topic devote on average $0.36 \%$ of the total space of their manifestos to specific mentions of candidates and $0.27 \%$ to general mentions of the issue). Furthermore, the same factors drive parties to mention both the specific candidates and the topic in general (see results in Appendix 5 and Appendix 6). Hence, we strongly consider that the time of nomination cannot explain the low salience of the topic among parties competing in the European Parliament elections.

${ }^{9}$ Two different coding categories with their respective positive and negative occurrences were available: "040801 Spitzenkandidaten general" (positive: favorable mentions of their general role in the EU; negative: negative mentions of their general role in the EU); "040802 Spitzenkandidaten specific" (positive: favorable mentions of a specific Spitzenkandidaten [i.e., Jean -Claude Juncker, Martin Schulz, Guy Verhofstadt, Ska Keller, José Bové and Alexis Tsipras]; negative: negative mentions of a specific Spitzenkandidaten [i.e., Jean-Claude Juncker, Martin Schulz, Guy Verhofstadt, Ska Keller, José Bové and Alexis Tsipras]). 
differentiate between parties that belong to a group which supported a candidate on the one hand and parties that are part of the two EP groups which did not nominate a candidate or were part of it before the elections, and those parties belonging to groups that nominated their candidate only after longer intraparty debates on the other hand. The position of the party supporters (H3) is computed as the mean self-reported stances on European integration ranging from 0 "has already gone too far" to 10 "should be pushed further" (subsequently rescaled to take values between 0 and 1 ) of those who report that they feel close to the given party based on the data from the 2014 EES Voter's Study (Schmitt et al. 2015). The position of parties towards the EU (H4) is measured by using the “EU_position" variable from the 2016 Chapel Hill Expert Study (Bakker et al. 2015) ${ }^{11}$.

Furthermore, we control for the governing status of a party by using the Parlgov data set (Döring and Manow 2015), the size of the party (i.e. proportion of votes obtained in the 2014 EP elections), if the document is a proper electoral manifesto or another type of document (i.e., 'official' election-related document, manifesto of party leader, extract from the national manifesto, or any other party document), and the size of the party manifesto. ${ }^{12}$ Moreover, having learned about the pronounced differences among countries in terms of media coverage and the citizens' awareness of the candidates from previous studies, we will try to capture these possible home country effects adding a dummy variable that takes the value " 1 " when parties are based in the same country as one of the Spitzenkandidaten.

\footnotetext{
${ }^{10}$ As a sensitivity checks we also use the 1) EP party group a party joined after the 2014 EP elections and 2) the EP group a party belonged in the $7^{\text {th }}$ European Parliament (in this later case for parties that did not compete in 2009 EP elections and for parties that did not gain seats after the 2009 EP elections we impute the EP party group they joined after the 2014 EP elections), see Appendix 11.

${ }^{11}$ We prefer the CHES measure to party position measures based on Manifestos given that it considered as a more reliable position of the "true" party stances in regards to European integration that measure that can be inferred based of the text of the manifesto. Part of the reason for this being the case is that party manifestos are drafted having in mind strategic consideration, hence the position based of manifesto might not be "true" position of the party but how the party would like to be perceived. In fact, previous studies show that CHES measures outperform the manifestos based measure of scaling of the text of the manifestos (Marks et al., 2007; Netjes and Binnema, 2007). Furthermore, sensitivity checks based on the manifesto based measure of the EU position of the party yields same substantive conclusions (see Appendix 10).

${ }^{12}$ Using more extended model specifications that control for a number of other facts reveals a very similar pattern of results see Appendixes 7 and 8.
} 


\section{Analysis}

We start with an overview of the parties that include the Spitzenkandidaten topic in their manifestos (see Appendix 1). Only 37 out of the 199 parties in our data make reference to the Spitzenkandidaten topic; furthermore, the parties that mention the topic devote less than $1 \%$ of the space of their manifesto to it. Taking into account all manifestos, we can note that parties devote on average around $0.12 \%$ of the manifesto's space to the Spitzenkandidaten topic $^{13}$. This is less than what parties dedicate to other "new" topics that are less significant for the future of the EU, e.g. the Ukraine conflict, which is covered by 39 parties and is assigned around $0.17 \%$ of the space across all manifestos. Moreover, the Spitzenkandidaten topic is insignificant compared to one of the most salient topics in the manifestos, i.e., social justice, which is mentioned by 170 parties and is assigned around $4.1 \%$ of the space across all manifestos. In fact, the Spitzenkandidaten issue is among one of the least mentioned in the Euromanifestos and only comparable to issues such as "Socialist property", "Nationalization" or "Voting procedures in the Council". Hence, we conclude that most parties chose to ignore the topic, and those who didn't, devote very little space to it. However, the overall tone is consistently positive, with only two exceptions-the Danish "Konservative Folkepartit" and the Greek "Kommounistiko Komma Ellados". Moreover, this first descriptive overview brings partial support for H1. It seems that parties belonging to EP groups which nominated a candidate are more likely to mention the topic, as only one party from the two EP groups that did nominate a candidate brought forward the topic.

In the next step of our analysis, we provide a more rigorous quantitative analysis of the factors that determine both the salience and the framing of the topic to test our hypotheses. Before presenting the results in Table 1, we need to make a few observations. First, we chose to use a simple categorical variable in order to measure the attention the party dedicates to the Spitzenkandidaten

\footnotetext{
${ }^{13}$ This number was computed by summing up the proportion of quasi-sentences mentioning the topic across all parties and dividing it by the total number of manifestos (i.e., parties) in our data.
} 
topic $^{14}$, given that even the parties that mention the topic devote very little space to it. Second, as we do not consider that not mentioning the issue is reflective of the Spitzenkandidaten topic, when analyzing how parties frame the topic we only include the parties that mention the candidates. Third, as EP group membership and the position of parties on EU integration are highly correlated, we decided to include them in separate models. Last but not least, while all results presented in Table 1 are based on multilevel models, we need to point out that Models 1 to 4 (i.e., the ones predicting the mentions of the Spitzenkandidaten topic) are generalized linear multilevel models which use a logistic link function, while Models 5 to 7 (i.e., the ones predicting the framing of the Spitzenkandidaten topic) are simple linear multilevel models.

\section{[Table 1 around here]}

The results presented in Table 2 bring support to almost all of our hypotheses. Accordingly, Model 1 supports $\mathrm{H} 1.1$, as parties belonging to an EP group that nominated a candidate are on average 9 times more likely to mention the Spitzenkandidaten topic. Furthermore, this variable also has a positive and statistically significant impact on the propensity of parties to frame the topic in a positive way (see Model 5), hence supporting H1.2. On the other hand, we do not find any evidence that parties belonging to the EPP group are less likely to make references to the topic ( $\mathrm{H} 2)$, given the internal divisions that marked the nomination procedure of the group (see Model 2) ${ }^{15}$.

We also find evidence to support H4.1, as Model 3 shows that an anti-pro EU orientation of a party has a positive and statically significant effect on its propensity to mention the Spitzenkandidaten

\footnotetext{
${ }^{14}$ The results are very similar when performing a sensitive check for which we use the untransformed variable and employ tobit regression models pulled across all countries (see Appendix 2). Using models with random slopes for the independent variables of interests yields the same substantive conclusions.

${ }^{15}$ Disaggregating the EP group variable by include dummy variables for each party groups (with the EPP as a reference category) shows that the only statistically significant difference can be noted between the EPP and the parties that do not have a Spitzenkandidaten (i.e. ECR+EFD and non-affiliated and non-EP groups). At the same time, no statically significant difference can be noted between parties that nominated a candidate (see Appendix 9).
} 
topic $^{16}$. What can further be observed is that moving from an extreme anti-EU position to an extreme pro-EU position increases the probability for a party to mention the topic by approximately 20 percentage points (see Figure 1). This result is robust across operationalization, since using the untransformed measure of salience yields the same substantive results (see Appendix 2). ${ }^{17}$ As expected, we also find support for H4.2, since parties adopting more pro-EU stances are also more likely to use a positive tone when mentioning the topic. We can contrast the effect of the party position on the anti-pro EU axis with the position of party supporters on the same axis. As a reminder, it might as well be the case that the position supporters dictate what parties choose to emphasize in their manifestos (H3). When testing this hypothesis, it is further important to mention that, due to the high correlation between the party position and the supporters' position, including them both in the same model would lead to multicollinearity. This being said, we can note that the EU stance of party supporters has a positive and statically significant impact only on how parties frame the topic but not on the salience. ${ }^{18}$

\section{[Figure 1 around here]}

Altogether, our findings show that the emphasis of the topic under investigation is determined by three main factors. First, if the party belongs to an EP party group supporting one of the candidates, the Spitzenkandidaten system is more likely to be salient for the party. Second, the party's general

\footnotetext{
${ }^{16}$ Using a measure of the party anti-pro EU orientations which is based on the difference between positive and negative mentions of quasi-sentences regarding EU constitutive issues as coded by the EES 2014 Euromanifesto Study (Schmitt et al. 2016), reveals an identical patter of results, see Appendix 10.

${ }^{17}$ In subsequent models we also controlled for how salient the EU issue is for the party and the degree of intraparty dissent regarding this issue (both measured by the 2015 CHES data). None of these effects reached statistical significance, and adding them to the model did not impact the substantive effect of the other variables. ${ }^{18}$ Including both the party position and the position of supporters in the same model does not change the substantive findings for the salience models, but it renders effects statically insignificant in the case of the framing model (see Appendix 3). Furthermore, it is important to note that the results are similar when computing the position of supporters based either on the 2009 EES Voter Study or the 2012 European Social Survey (see Appendix 4).
} 
position towards the EU is influential: pro-EU parties are more likely to both mention the Spitzenkandidaten topic and frame it in a more positive light than others. Third, if supporters of a party are more pro-EU, the party is also more likely to frame the topic in a positive light. However, we did not find that the position of supporters also has an impact on salience. Moreover, the findings show clearly that if the candidate stems from the country in which the party runs for the EP election, the Spitzenkandidaten system is much more salient: I.e. political parties from the countries of the candidates are on average almost six times more likely to make reference to the Spitzenkandidaten topic in their manifestos.

\section{Conclusion}

Originally, the key institutional changes introduced in line with the Lisbon Treaty (2009) were widely expected to have an impact on the relevance of EP elections (Follesdal and Hix 2006). Previous studies show that although the Spitzenkandidaten system had an impact on public opinion, this effect was relatively minor (Maier et al. 2017; Schmitt et al. 2015). Accordingly, scholars agree that "the Spitzenkandidaten process produced something of a supranational moment in the evolution of the EU's institutional architecture" (Christiansen 2016: 1006, Schmitt et al. 2016), but that these changes "hardly amount to the kind of critical juncture that would throw the Union off its established path" (Christiansen 2016: 1007). Against this background, the aim of this study was to explore the reasons for this pattern investigating the behavior of the most important actors in this regard: political parties. Accordingly, we asked whether the prospect of providing the president of the European Commission affected parties' behavior in their electoral campaigns.

The findings of our empirical analyses show that the majority of the parties running for the 2014 EP elections did not put much emphasis on the candidates themselves or on the Spitzenkandidaten system - and the few parties who did mention it dedicated only very little space of their manifestos to the topic. Obviously, disregarding the normative benefits, i.e. the prospect of more 
legitimacy for EP elections and the EU in general, as evident by the low salience of the topic (see Appendix 1), parties saw little strategic reason why emphasizing the Spitzenkandidaten topic should be advantageous for their cause. Referring to the well-known models of competitive party behavior (Müller/Strom 1999; Strom 1990), we were able to confirm this pattern empirically and to discern how strategic considerations indeed impact the salience a party devotes to the topic.

Their office-seeking nature - operationalized through the idea of whether parties belong to EP party groups that nominated a candidate - and their policy-seeking nature - operationalized through their anti-pro EU position - partly determine the emphasis political parties put on the Spitzenkandidaten topic. The (rather few) parties which emphasized the topic obviously considered that the benefits of this institutional change could play in favor of their pro-EU rhetoric enabling them to pursue their pro-EU polities and policies (policy seeking rationale), or even less sophisticated: The parties tried to benefit from this institutional change to get their own national party representatives into office (office seeking rationale). Nonetheless, we need to emphasize that the explanatory power of these factors is rather limited given the low numbers of parties that choose to mention the Spitzenkandidaten topic even if they belong to an EP group that nominated a candidate and/or even if their potential voters are rather supportive of the union. Furthermore, we need to note that this is not a complete list of strategic consideration that potentially impact the salience of the topic. As previously mentioned, due to data restrictions, we only have a very imperfect measure of how dissent between parties belonging to the same EP group influence their decision to mention the topic (but see footnote 4 for a detailed explanation). Although getting more fine grained data on this aspect is simply impossible, this could be ideally tested in a more appropriate way in the upcoming 2019 EP elections.

In contrast to the findings we were able to present above, the genuine vote-seeking motivation, which we operationalized through the idea of how well parties listen to their voters, only played a role for the tone but not the salience of the topic - i.e. once they mentioned the topic, their approach to it was guided by the attitudes of their potential voters. Responsible for this could be the particularities of the EU multi-level system that renders pure vote-maximation a complex issue. This is 
insofar compelling as we know from the literature on second-order EP elections (Schmitt/Reif 1980; Schmitt 2005) that voters behave differently in EP elections than in national elections. Another significant finding that needs to be also interpreted with reference to the particular multi-level setting of the EU is the fact that political parties put more emphasis on the Spitzenkandidaten system in case that the candidate stemmed from their own country. Parties obviously tend to promote the institutional changes more often, when other parties within their (national) party system, address this topic.

To sum up, although the institutional changes aimed high and sought to create a genuine panEuropean contest, our findings clearly show that the main actors in this contest, the national political parties, did not make these elections that different, because most parties ignored the strategic considerations that would have made this a fruitful topic. This has important implications for the future of EP elections. A pessimist view on our results would be that the lack of a transnational party system cannot be only achieved by means of national political parties, but rather by taking into account the Europarties (see also Gagatek 2016). This would imply a more profound transformation of party politics within the EU multi-level system. In this line of reasoning, a simple relaunch of the procedure in the 2019 EP elections would lead to an identical - and at least for the proponents of the Spitzenkandidaten system disappointing - result. In a more optimist perspective, however, one could conclude that by creating a larger audience for the Spitzenkandidaten (procedure) in future EP elections by the media (Maier et al. 2017), and even more importantly by offering specific incentives to the national political parties, the $2019 \mathrm{EP}$ elections could be different. In this regard, it would be likewise interesting to know more about party behavior via the less traditional channels of party communication, such as social media. While manifestos are intermediaries between the party, the candidates, and the public, and are thus responsible for the indirect communication between parties and voters, social media is rather in charge for the communication between candidates and the public. Hence, contrasting the two channels might represent a very fruitful endeavor for further investigations. To be more precise, future research might analyze the salience of the topic over both manifestos and social media and also 
instigate how successful the two channels are in raising awareness about this new political development among the general public. 
Table 1: Determinants of salience and framing of the Spitzenkandidaten topic

\begin{tabular}{|c|c|c|c|c|c|c|c|}
\hline & $\begin{array}{l}\text { Model } 1 \\
\text { (salience, } \\
\text { office- } \\
\text { seeking) }\end{array}$ & $\begin{array}{l}\text { Model } 2 \\
\text { (salience, } \\
\text { dissent) }\end{array}$ & $\begin{array}{l}\text { Model } 3 \\
\text { (salience, } \\
\text { policy- } \\
\text { seeking ) }\end{array}$ & $\begin{array}{l}\text { Model } 4 \\
\text { (salience, } \\
\text { vote- } \\
\text { seeking) }\end{array}$ & $\begin{array}{l}\text { Model } 5 \\
\text { (framing, } \\
\text { office- } \\
\text { seeking) }\end{array}$ & $\begin{array}{l}\text { Model } 6 \\
\text { (framing, } \\
\text { policy- } \\
\text { seeking) }\end{array}$ & $\begin{array}{l}\text { Model } 7 \\
\text { (framing, } \\
\text { vote- } \\
\text { seeking ) }\end{array}$ \\
\hline \multicolumn{8}{|l|}{ Fixed effects } \\
\hline \multirow[t]{2}{*}{ Intercept } & $-5.176^{* * *}$ & $-2.222^{*}$ & $-5.054^{* * *}$ & $3.553 * *$ & 0.529 & 0.080 & -0.564 \\
\hline & $(1.370)$ & $(1.148)$ & $(1.378)$ & $(1.463)$ & $(0.637)$ & $(0.463)$ & $(0.638)$ \\
\hline EP group of & $3.046^{* * *}$ & & & & 0.176 & & \\
\hline Spitzenkandidaten & (1.145) & & & & $(0.564)$ & & \\
\hline EP group without & & $-2.926^{* *}$ & & & & & \\
\hline candidate & & $(1.170)$ & & & & & \\
\hline \multirow[t]{2}{*}{ EPP } & & 0.475 & & & & & \\
\hline & & $(0.520)$ & & & & & \\
\hline EU position & & & $3.172^{* * *}$ & & & $0.802^{* *}$ & \\
\hline (party) & & & $(1.140)$ & & & $(0.366)$ & \\
\hline EU position & & & & 0.829 & & & $2.367^{* *}$ \\
\hline (supporters) & & & & $(2.276)$ & & & $(1.000)$ \\
\hline \multirow[t]{2}{*}{ Incumbent party } & -0.124 & -0.148 & -0.200 & 0.363 & -0.008 & -0.089 & 0.153 \\
\hline & (0.519) & $(0.522)$ & $(0.550)$ & $(0.530)$ & $(0.204)$ & (0.189) & $(0.216)$ \\
\hline \multirow[t]{2}{*}{ EP votes share } & 2.293 & 1.898 & 1.626 & 2.219 & 1.157 & 0.990 & 1.688 \\
\hline & $(2.230)$ & $(2.305)$ & $(2.231)$ & (2.044) & (1.011) & (0.990) & $(1.076)$ \\
\hline \multirow[t]{2}{*}{ Manifesto size } & 2.133 & 2.061 & $2.563^{*}$ & 1.967 & $-0.942^{*}$ & $-0.976^{* *}$ & $-1.095^{* *}$ \\
\hline & $(1.356)$ & $(1.363)$ & (1.432) & $(1.351)$ & $(0.498)$ & $(0.491)$ & (0.549) \\
\hline \multirow[t]{2}{*}{ Proper manifesto } & -0.457 & -0.438 & -0.129 & 0.249 & -0.098 & -0.117 & -0.208 \\
\hline & $(0.958)$ & (0.969) & $(0.945)$ & $(0.826)$ & $(0.335)$ & $(0.313)$ & $(0.337)$ \\
\hline Home country of & $1.688^{* *}$ & $1.698^{* *}$ & $1.881^{* *}$ & $1.693^{* *}$ & 0.033 & 0.137 & 0.225 \\
\hline Spitzenkandidaten & $(0.790)$ & $(0.783)$ & $(0.865)$ & $(0.743)$ & $(0.204)$ & (0.219) & $(0.268)$ \\
\hline \multicolumn{8}{|l|}{$\begin{array}{l}\text { Random effects } \\
\text { (variance) }\end{array}$} \\
\hline Intercept & 1.176 & 1.116 & 1.472 & 0.766 & 0.000 & 0.042 & 0.093 \\
\hline Residuals & & & & & 0.282 & 0.212 & 0.196 \\
\hline AIC & 155.993 & 157.167 & 150.511 & 139.497 & 66.228 & 61.693 & 53.315 \\
\hline $\mathrm{BIC}$ & 181.756 & 186.151 & 175.407 & 163.256 & 79.696 & 74.885 & 64.977 \\
\hline Log Likelihood & -69.997 & -69.584 & -67.255 & -61.749 & -24.114 & -21.847 & -17.657 \\
\hline $\mathrm{N}$ (parties) & 185 & 185 & 166 & 144 & 33 & 32 & 27 \\
\hline $\mathrm{N}$ (country) & 28 & 28 & 28 & 28 & 16 & 16 & 15 \\
\hline
\end{tabular}

Note: Table entries are logit coefficients for Models 1 to 4 , respectively unstandardized regression coefficients for Models 5 to 7 , standard errors in parenthesis; ${ }^{* * *}$ denotes $p<0.01,{ }^{* *}$ denotes $p<0.05,{ }^{*}$ denotes $p<0.1$ 
Figure 1: Predicted probability to mention the Spitzenkandidaten topic depending on anti-pro EU position of parties.

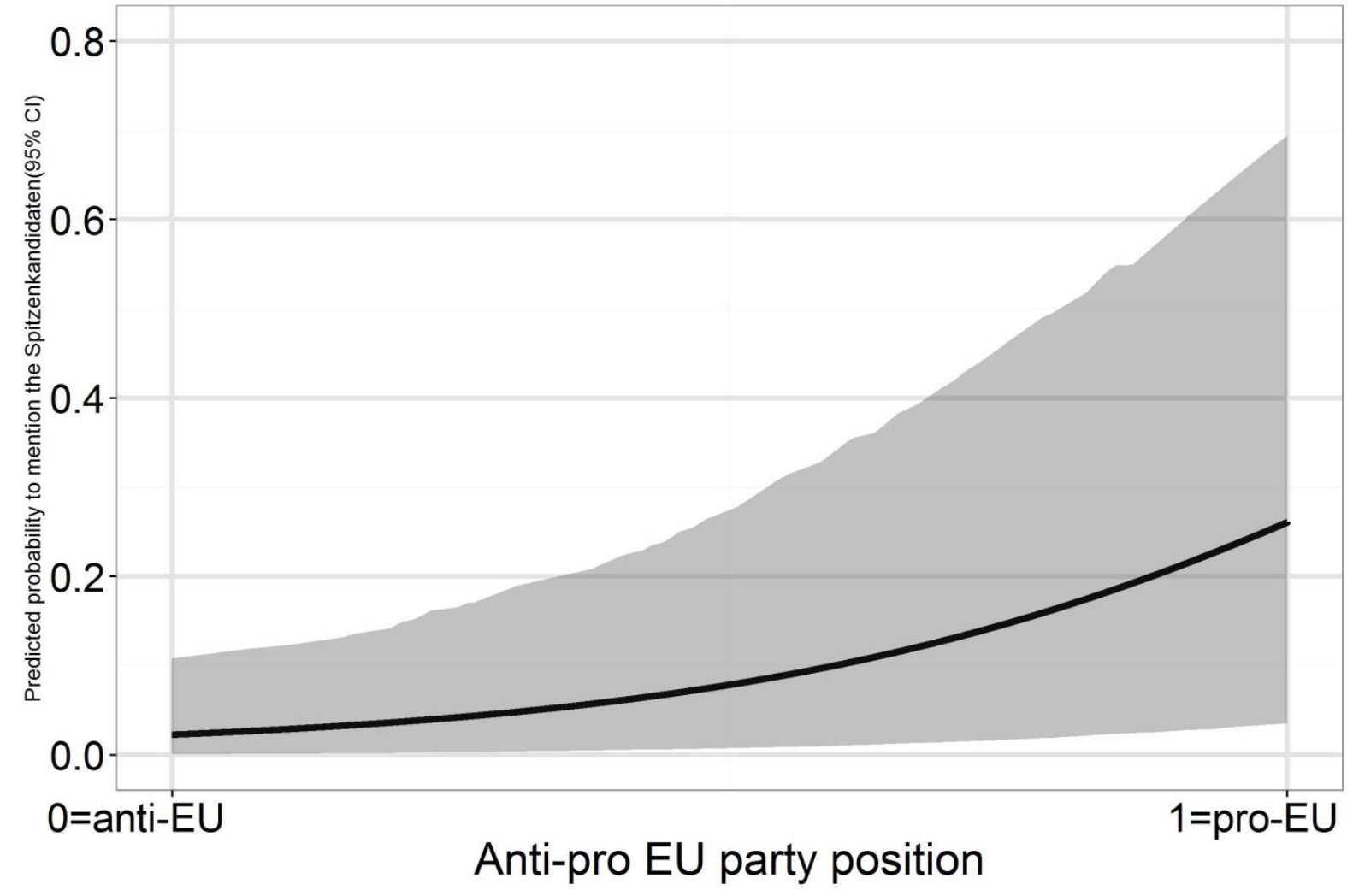




\section{References}

Adams, James, Lawrence Ezrow, and Zeynep Somer-Topcu (2014). 'Do Voters Respond to Party Manifestos or to a Wider Information Environment? An Analysis of Mass-Elite Linkages on European Integration', American Journal of Political Science, 58: 4, 967-78.

Bakker, Ryan, and et al. (2015). 'Measuring party positions in Europe: The Chapel Hill expert survey trend file, 1999-2010', Party Politics, 21: 1, 143-52.

Bélanger, Éric, and Bonnie M. Meguid (2008). 'Issue salience, issue ownership, and issue-based vote choice', Electoral Studies, 27: 3, 477-91.

Braun, Daniela, Swen Hutter, and Alena Kerscher (2016). 'What type of Europe? The salience of polity and policy issues in European Parliament elections', European Union Politics, 17: 4, 570-92.

Braun, Daniela, Hermann Schmitt, Andreas M. Wüst, Sebastian Adrian Popa, Slava Mikhaylov, and Felix Dwinger (2015). European Parliament Election Study 1979-2009, Manifesto Study. GESIS Datenarchiv, Köln: ZA5102 Datenfile Version 1.0.0, doi:10.4232/1.5102.

Budge, lan, and Dennis Farlie (1983). Explaining and Predicting Elections: Issue Effects and Party Strategies in Twenty-Three Democracies. London: George Allen \& Unwin.

Budge, lan, Hans-Dieter Klingemann, Andrea Volkens, Judith Bara, and Eric Tannenbaum, eds. (2001). Mapping Policy Preferences: Estimates for Parties, Electors, and Governments 1945-1998. Oxford: Oxford University Press.

Ceron, Andrea (2012).'Bounded Oligarchy: How and When Factions Constrain Leaders in Party Position-taking', Electoral Studies, 31: 4, 689-701.

Christiansen, Thomas (2016). 'After the Spitzenkandidaten: fundamental change in the EU's political system?', West European Politics, 39: 5, 992-1010.

Corbett, Richard (2014). "European Elections are Second-Order Elections': Is Received Wisdom Changing', Journal of Common Market Studies, 52: 6, 1194-98.

de Vries, Catherine E., and Sara B. Hobolt (2016): EU Issue Voting in National and European Parlamentary Elections, in W. van der Brug and C. de Vreese (eds.), (Un)intended Consequences of European Parliamentary Elections. Oxford: Oxford University Press, 101-124.

Döring, Holger, and Philipp Manow (2015). 'Parliaments and governments database (ParlGov): Information on parties, elections and cabinets in modern democracies.' Development version, available at: http://www.parlgov.org (accessed 08 April 2016).

Edwards Erica Elizabeth (2008). 'Intra-Party Dissent over European Integration', Chapel Hill: Dissertation, University of North Carolina.

European Parliament (2014).The 2014 European Elections: This Time It's Different, available at http://www.europarl.europa.eu/pdfs/news/expert/background/20140210BKG35568/20140 210BKG35568_en.pdf (accessed 18 July 2017).

Follesdal, Andreas, and Simon Hix (2006). 'Why there is a democratic deficit in the EU: A response to Majone and Moravcsik', Journal of Common Market Studies, 44: 3, 533-562.

Franklin, Mark N. (2014). 'Why vote at an election with no apparent purpose? Voter turnout at elections to the European Parliament', European Policy Analysis, 2014: 4.

Gagatek, Wojciech (2016). 'Perspectives on the development of a transnational party system in the European Union after the 2014 elections to the European Parliament', in Ferdinand MüllerRommel, and Fernando Casal Bértoa (eds.), Party Politics and Democracy in Europe. London/ New York: Routledge, 148-161.

Gattermann, Katjana, Claes H. De Vreese, and Wouter Van Der Brug (2016). 'Evaluations of the Spitzenkandidaten: The Role of Information and News Exposure in Citizens' Preference Formation', Politics and Governance, 4: 1, 37-54.

Green-Pedersen, Christoffer (2007). 'The Growing Importance of Issue Competition: The Changing Nature of Party Competition in Western Europe', Political Studies, 55: 3, 607-28. 
Green, Jane, and Sara Hobolt (2008). 'Owning the issue agenda: Party strategies and vote choices in British elections', Electoral Studies, 27: 3, 460-76.

Greene, Zachary David, and Matthias Haber (2015). 'The consequences of appearing divided: an analysis of party evaluations and vote choice'. Electoral Studies, 37: 3, 15-27.

Hellström Johann and Blomgren Magnus (2015). 'Party debate over Europe in national election campaigns: Electoral disunity and party cohesion'. European Journal of Political Research 55, 265-282.

Hix, Simon (2005). The Political System of the European Union. Houndsmills, Basingstoke, Hampshire: Palgrave Macmillan.

Hix, Simon, and Michael Marsh (2011). 'Second-order effects plus pan-European political swings: An analysis of European Parliament elections across time', Electoral Studies, 30: 1, 4-15.

Hobolt, Sara B., Spoon, Jae-Jae, and James Tilley (2009). 'A Vote Against Europe? Explaining Defection at the 1999 and 2004 European Parliament Elections' British Journal of Political Science, 39: 1, 93-115.

Hobolt, Sara B., and Jae-Jae Spoon (2012). 'Motivating the European Voter: Parties, Issues and Campaigns in European Parliament Elections', European Journal of Political Research, 51: 6, 701-27.

Hobolt, Sara (2014). 'A vote for the President? The role of Spitzenkandidaten in the 2014 European Parliament elections', Journal of European Public Policy, 21: 10, 1528-40.

Lowe, Will, Benoit, Kenneth, Mikhaylov, Slava, and Michael Laver (2011). 'Scaling policy preferences from coded political texts', Legislative Studies Quarterly, 36: 1, 123-155.

Meguid, Bonnie M. (2008). Party Competition between Unequals: Strategies and Electoral Fortunes in Western Europe. Cambridge: Cambridge University Press.

Maier, Jürgen, et al. (2017).'This time it's different? Effects of the Eurovision Debate on young citizens and its consequence for EU democracy - evidence from a quasi-experiment in 24 countries', Journal of European Public Policy, doi: 10.1080/13501763.2016.1268643.

Müller, Wolfgang C. and Kaare Strom (1999): Policy, Office, or Votes? How Political Parties in Western Europe Make Hard Decisions. Cambridge: Cambridge University Press.

Nulty, Paul, Yannis Theocharis, Sebastian Adrian Popa, Olivier Parnet, and Kenneth Benoit (2016). 'Social Media and Political Communication in the 2014 Elections to the European Parliament', Electoral Studies, 44: 429-444.

Peñalver García, Nereo and Julian Priestley (2015). The Making of a European President. Houndmills: Palgrave Macmillan UK.

Petrocik, John R. (1996). 'Issue Ownership in Presidential Elections, with a 1980 Case Study', American Journal of Political Science, 40: 3, 825-50.

Petrocik, John R., William L. Benoit, and Glenn J. Hansen (2003). 'Issue Ownership and Presidential Campaigning, 1952-2000', Political Science Quarterly, 118: 4, 599-626.

Pop, Valentina (2014). 'Buses, selfies, posters: EU campaign in full swing', EUobserver, available at https://euobserver.com/eu-elections/124152 (accessed 01 April 2016),

Popa, Sebastian Adrian, and Delia Dumitrescu (2015). 'National but European? Visual manifestations of Europe in national parties Euromanifestos since 1979', Party Politics (published online before print), doi: 10.1177/1354068815610963.

Put, Gert-Jan, Steven van Hecke, Corey Cunningham, and Wouter Wolfs (2016).'The choice of spitzenkandidaten: A comparative analysis of the Europarties' selection procedures', Politics and Governance, 4: 1, 9-22.

Reif, Karlheinz and Hermann Schmitt (1980). 'Nine Second-Order National Elections - A Conceptual Framework for the Analysis of European Election Results', European Journal of Political Research, 81: 1, 3-44.

Schmitt, Hermann (2005). 'The European Parliament Elections of June 2004: Still Second-Order?', West European Politics, 28: 3, 650-79. 
Schmitt, Hermann, Daniela Braun, Sebastian Adrian Popa, Slava Mikhaylov, and Felix Dwinger (2016). 'European Parliament Election Study 2014, Euromanifesto Study', GESIS Datenarchiv, Köln. ZA5162 Datenfile Version 1.0.0, doi: 10.4232/1.5162.

Schmitt, Hermann, Sara Hobolt, and Sebastian Adrian Popa (2015). 'Does personalization increase turnout? Spitzenkandidaten in the 2014 European Parliament elections', European Union Politics, 16: 3, 347-68.

Schmitt, Hermann, and Eftichia Teperoglou (2015). 'The 2014 European Parliament Elections in Southern Europe: Second-Order or Critical Elections?', South European Society and Politics, 20: 3, 287-309.

Schmitt, Hermann, and Ilke Toygür (2016). 'European Parliament Elections of May 2014: Driven by National Politics or EU Policy Making?', Politics and Governance, 4: 1, 167-81.

Schulze, Heidi (2016). 'The Spitzenkandidaten in the European Parliament Election Campaign Coverage 2014 in Germany, France, and the United Kingdom', Politics and Governance, 4: 1, 23-36.

Steenbergen Marco R. and Scott David J. (2004). 'Contesting Europe? The salience of European integration as a party issue', in Gary Marks, and Marco R. Steenbergen (eds), European Integration and Political Conflict. Cambridge: Cambridge University Press, 165-192.

Steenbergen, Marco R., Erica E. Edwards, and Catherine E. de Vries (2007). 'Who's cueing whom? Masselite linkages and the future of European integration', European Union Politics, 8: 1, 13-35.

Strom, Kaare (1990): 'A Behavioral Theory of Competitive Political Parties', American Journal of Political Science, 34:. 2, 565-598.

van der Brug, Wouter, and Claes de Vreese, eds. (2016): (Un)intended Consequences of European Parliamentary Elections. Oxford: Oxford University Press.

Wagner, Markus, and Thomas Meyer (2014). 'Which Issues do Parties Emphasise? Salience Strategies and Party Organisation in Multiparty Systems', West European Politics, 37: 5, 1019-45.

Wüst, Andreas, and Hermann Schmitt (2007). 'Comparing the Views of Parties And Voters in the 1999 Election to the European Parliament', in Wouter van der Brug, and Cees van der Eijk (eds.), European Elections and Domestic Politics. Lessons from the past and scenarios for the future. Notre Dame: University of Notre Dame Press, 73-93. 